\title{
Economics with Market Liquidity Risk
}

\author{
Acharya, Viral V.; Pedersen, Lasse Heje
}

Document Version

Accepted author manuscript

Published in:

Critical Finance Review

DOI:

10.1561/104.00000083

Publication date:

2019

License

Unspecified

Citation for published version (APA):

Acharya, V. V., \& Pedersen, L. H. (2019). Economics with Market Liquidity Risk. Critical Finance Review, 8(1-2), 111-125. https://doi.org/10.1561/104.00000083

Link to publication in CBS Research Portal

\section{General rights}

Copyright and moral rights for the publications made accessible in the public portal are retained by the authors and/or other copyright owners and it is a condition of accessing publications that users recognise and abide by the legal requirements associated with these rights.

Take down policy

If you believe that this document breaches copyright please contact us (research.lib@cbs.dk) providing details, and we will remove access to the work immediately and investigate your claim. 


\section{Economics with Market Liquidity Risk}

\section{Viral V. Acharya and Lasse Heje Pedersen}

Journal article (Accepted manuscript*)

\section{Please cite this article as:}

Acharya, V. V., \& Pedersen, L. H. (2019). Economics with Market Liquidity Risk. Critical Finance Review, 81-2), 111-125. https://doi.org/10.1561/104.00000083

The final publication is available from now publishers via https://doi.org/10.1561/104.00000083

* This version of the article has been accepted for publication and undergone full peer review but has not been through the copyediting, typesetting, pagination and proofreading process, which may lead to differences between this version and the publisher's final version AKA Version of Record.

Uploaded to CBS Research Portal: February २०२० 


\title{
Economics with Market Liquidity Risk
}

\author{
Viral V. Acharya and Lasse Heje Pedersen ${ }^{*}$
}

\begin{abstract}
For markets to work efficiently, buyers and sellers must be able to transact easily. People must have access to a marketplace such as a supermarket or a stock exchange with adequate liquidity. Further, people must have confidence that such a well-functioning marketplace will also exist in the future. Market liquidity risk is the risk that the market will function poorly in the future, handcuffing the "invisible hand" through which markets produce allocative efficiency. We discuss the effects of market liquidity risk on asset pricing, investment management, corporate finance, banking, financial crises, macroeconomics, monetary policy, fiscal policy, and other economic areas.
\end{abstract}

\footnotetext{
* Acharya is at New York University, Stern School of Business. Pedersen is at AQR Capital Management, Copenhagen Business School, NYU, and CEPR. We are grateful for helpful comments from Yakov Amihud. AQR Capital Management is a global investment management firm, which may or may not apply similar investment techniques or methods of analysis as described herein. The views expressed here are those of the authors and not necessarily those of $A Q R$.
} 
We thank the authors of papers ${ }^{1}$ replicating our study on asset pricing with liquidity risk (Acharya and Pedersen, 2005). We are grateful for this opportunity to reconsider our findings, review the literature, and consider broader applications. We comment on the replication in Section 1, but let us start by considering the economics of market liquidity risk at a broader level.

Most developed, and increasingly even developing, countries in the world rely on a market-based economic system, since markets provide a relatively efficient and decentralized way of allocating resources. Markets are used to allocate investments to savers, capital to entrepreneurs, and jobs to workers. For markets to work efficiently, buyers and sellers must be able to transact easily. People must have access to a marketplace such as a supermarket or a stock exchange with adequate liquidity. Said differently, markets must be liquid. Furthermore, people must have confidence that such a wellfunctioning marketplace will also exist in the future. Buyers who think that they might want to sell in the future need to know that they will continue to have access to a market. The risk that the market will function poorly in the future is what we call market liquidity risk.

Economic prosperity depends critically on well-functioning institutions, both those run by the state as well as the market. Just as people would not let the police, courts, or fire departments close down, they worry about the liquidity risk of the markets where they participate. For example, a homeowner may worry about the liquidity risk of the housing market, a shareholder may worry about the liquidity risk of the equity market, a firm with financing needs may worry about the liquidity risk in the corporate bond market, and an indebted government may worry about the liquidity risk in the government bond market.

Market liquidity risk therefore has broad economic implications. Market liquidity risk affects how investment managers structure their portfolios; these portfolio decisions affect equilibrium asset prices, and, therefore, the cost of capital of firms and governments. The cost of capital in turn affects how firms decide to invest, issue securities, and structure their balance sheets. Further, aggregate firm investments influence employment and macroeconomic growth, so managing market liquidity risk becomes a tool for monetary policy, especially during financial crises. Fiscal policy depends on a government's ability to issue debt, that is, the market liquidity of the government bond markets, and liquidity effects can be particularly strong for developing economies in emerging markets.

The rest of this paper discusses the effects of market liquidity risk in each of these areas. Given that we touch on a wide variety of economic disciplines, we cannot give a full literature review of each area, but, rather, we will limit ourselves to citing a few recent examples of liquidity risk in each area.

\section{Asset pricing with market liquidity risk}

A central question in asset pricing is determining the required return, $\mathrm{E}_{t}\left(r_{t+1}^{i}\right)$, for any security $i$ at any time $t$. Indeed, buyers of the security must consider what return they can expect, and conversely, the

\footnotetext{
${ }^{1}$ Holden and Nam (2019) and Kazumori, Fang, Sharman, Takeda, and Yu (2019) in this issue.
} 
issuer of the security is interested in the cost of capital. The standard formula for the required return is the classic capital asset pricing model (CAPM), stating that the expected return should depend on the amount of systematic risk measured by the market beta, which depends on the covariance between the return and the overall market return, $\operatorname{cov}_{t}\left(r_{t+1}^{i}, r_{t+1}^{M}\right)$. The general idea is that investors should care about the risk and expected return of their overall portfolio, so securities that contribute more to the overall portfolio risk must deliver a commensurate higher expected return.

Our model of liquidity risk extends this idea to the case in which there are trading costs, $c_{t+1}^{i}$, that vary across securities $i$ and over time $t$. For example, if an investor buys security $i$ at time $t$ and sells it at time $t+1$, then she earns a gross return of $r_{t+1}^{i}$, but a return net of trading costs of $r_{t+1}^{i}-c_{t+1}^{i}$. We are interested in how trading costs (i.e., illiquidity) and the risk of high future trading costs (i.e., liquidity risk) affect the required return. Our model shows in a relatively simple setting that the CAPM holds for net returns, which translates into the following liquidity-adjusted CAPM (LCAPM) for the expected gross return:

$$
\mathrm{E}_{t}\left(r_{t+1}^{i}\right)=r^{f}+\mathrm{E}_{t}\left(c_{t+1}^{i}\right)+\lambda_{t}\left(\beta_{t}^{1}+\beta_{t}^{2}-\beta_{t}^{3}-\beta_{t}^{4}\right)
$$

Here, $r^{f}$ is the risk-free interest rate, $\mathrm{E}_{t}\left(c_{t+1}^{i}\right)$ is the expected illiquidity cost, $\lambda_{t}$ is the risk premium, and the four betas measure different systematic market and liquidity risks. The risk-free rate is standard, but let us briefly provide some intuition for the other terms.

The first beta, $\beta_{t}^{1}=\frac{\operatorname{cov}_{t}\left(r_{t+1}^{i}, r_{t+1}^{M}\right)}{\operatorname{var}_{t}\left(r_{t+1}^{M}-c_{t+1}^{M}\right)}$, is essentially the standard market beta, capturing systematic market risk as discussed above. Further, the expected trading cost, $\mathrm{E}_{t}\left(c_{t+1}^{i}\right)$, raises the required return, because investors want to be compensated for buying an asset with associated trading costs. This term captures the spirit of the seminal paper by Amihud and Mendelson (1986), but part of the innovation of our model is to marry the Amihud and Mendelson (1986) model (which is based on risk-neutrality) with the standard CAPM. Indeed, in the special case in which trading costs are constant over time, our model is literally the marriage of the Amihud and Mendelson (1986) and the CAPM since the three liquidity betas are zero $\left(\beta_{t}^{2}=\beta_{t}^{3}=\beta_{t}^{4}=0\right)$. This simple version of the model may itself be useful, if we think that investors care most about market risk and average trading costs.

The three liquidity betas are also intuitive. Indeed, the first liquidity risk beta, $\beta_{t}^{2}=\frac{\operatorname{cov}_{t}\left(c_{t+1}^{i}, c_{t+1}^{M}\right)}{\operatorname{var}_{t}\left(r_{t+1}^{M}-c_{t+1}^{M}\right)^{\prime}}$ captures the idea that investors want to be compensated for holding a security that is particularly illiquid when securities are generally illiquid. Stocks tend to have positive values of $\beta_{t}^{2}$ because they exhibit "commonality in liquidity" (Chordia et al. (2000), Hasbrouck and Seppi (2001), and Huberman and Halka (1999)) and investors require a liquidity risk premium as a result of this liquidity comovement.

The next liquidity beta, $\beta_{t}^{3}=\frac{\operatorname{cov}_{t}\left(r_{t+1}^{i}, c_{t+1}^{M}\right)}{\operatorname{var}_{t}\left(r_{t+1}^{M}-c_{t+1}^{M}\right)}$, measures the co-movement of a security's gross return $r_{t+1}^{i}$ with the overall market illiquidity $c_{t+1}^{M}$. This term tends to be negative empirically, since stock prices tend to fall during times of overall illiquidity. Given the negative sign in the LCAPM, this form of liquidity 
risk also tends to raise the required return. This liquidity beta is similar to the standard market beta and other "factor loadings," where the factor here is the overall market illiquidity. The analysis of Pástor and Stambaugh (2003, also replicated in this issue) can be interpreted as an estimation of this liquidity risk premium.

The final liquidity beta, $\beta_{t}^{4}=\frac{\operatorname{cov}_{t}\left(c_{t+1}^{i}, r_{t+1}^{M}\right)}{\operatorname{var}_{t}\left(r_{t+1}^{M}-c_{t+1}^{M}\right)}$, measures a stock's liquidity sensitivity to market return moves. This term also tends to be negative because stock illiquidity tends to rise when the market crashes. As before, the negative coefficient in the LCAPM means that this form of systematic liquidity risk raises the required return.

Our model further shows that during a liquidity crisis when trading costs rise, required future returns increase (Proposition 2). This result is intuitive because, when illiquidity rises today, illiquidity is expected to stay elevated for a while due to its persistence (Amihud (2002, also replicated)) - and illiquidity may get even worse. Since investors need compensation to incur such elevated liquidity cost and risk, the required return rises.

When the required return increases, contemporaneous stock prices fall (Proposition 3). This fall in stock prices occurs because the stock price is the present value of future cash flows, which are now discounted more heavily. So the model makes the intuitive predictions that liquidity crises are associated with initially falling stock prices and rising future expected returns.

During the global financial crisis of 2007-2009, we saw an example of a liquidity crisis where trading costs skyrocketed for certain assets (mostly notably outside the equity market, in markets such as the convertible bond market) and prices dropped and later rebounded. When we presented our model before the global financial crisis, many researchers were skeptical of the importance of liquidity risk, but several told us that they changed their minds during the crisis (especially those involved with central banks or financial markets).

Science does not progress based on anecdotes, so we are extremely grateful for extensive replications and extension by the two sets of authors, Holden and Nam (2019) and Kazumori, Fang, Sharman, Takeda, and Yu (2019), and for the release of the code by Holden and Nam (about 10,000 lines of code for the replication and another 5,000 for their extensions). This effort is clearly extensive and, while these papers do not get exactly the same results as each other, and neither exactly match our results, we think that they meaningfully add to the overall evidence on the pricing of market liquidity risk.

Our original study concludes that "we find weak evidence that liquidity risk is important over and above the effects of market risk and the level of liquidity ... these results are estimated imprecisely because of collinearity". ${ }^{2}$ The standard CAPM is notoriously difficult to test and has repeatedly been rejected despite its continual use (see e.g., Fama and French, 2004, for a survey). Clearly, the LCAPM

\footnotetext{
${ }^{2}$ Page 405 in the conclusion of Acharya and Pedersen (2005).
} 
inherits many of the same estimation issues with the CAPM, plus more given the added complexity of the model, including the fact that illiquidity is not directly observable.

Both replication studies focus on testing the specific functional form of the LCAPM. They are able to reject the specific functional form, specifically the prediction that all betas have the same risk premium, $\lambda_{t}$. It is the hallmark of true science that a model can be rejected empirically, and we can view this finding as an accomplishment despite the estimation noise (not as a result of noise, assuming that the standard errors are correct).

Testing the specific functional form is interesting, but it is also interesting to consider the bigger issue of whether liquidity and liquidity risk matter for expected returns more generally. For this question, the results of the replications and extensions are far more encouraging. The majority of the significant coefficients have the model-implied signs, namely a positive sign for the average illiquidity $\mathrm{E}\left(c^{i}\right)$, a positive sign for commonality in liquidity, $\beta^{2}$, and negative signs for $\beta^{3}$ and $\beta^{4}$. (The signs of the insignificant coefficients have little meaning since they are estimated with so much noise that we cannot learn from these numbers.) $)^{3}$ In fact, the signs of the significant coefficients related to liquidity and liquidity risk tend to be correct more often than the sign of the significant coefficients related to the standard CAPM, $\beta^{1}$. For example, in the main replication (Table 3.B) and out-of-sample extension (Table 3.C), Holden and Nam (2019) find 7 significant coefficients for the level of liquidity $\mathrm{E}\left(c^{i}\right)$ and a number of significant liquidity risk coefficients, all with the right signs: 1 significant $\beta^{2}$ coefficient, 1 significant $\beta^{3}$ coefficient, 3 significant $\beta^{4}$ coefficients, and 8 significant $\beta^{\text {net }}$ coefficients ( $\beta^{\text {net }}$ is a combination of the other betas). The same two tables find 9 significant standard market betas $\beta^{1}, 7$ with the right signs and 2 with the wrong signs. In the corresponding tables by Kazumori et al. (2019, Table 4A, the panels labelled "Replication" and "Recent U.S." out-of-sample), we can count the significant coefficients by counting numbers for which the absolute $t$-statistic is greater than 1.64 (or, alternatively, greater than 1.96, which yields similar counts). We see 2 significant coefficients for the liquidity level and 8 significant coefficients of liquidity risk, $\beta^{\text {net }}$, all but one with the right sign. The standard market beta, $\beta^{1}$, has 6 significant coefficients, 3 with the right sign and 3 with the wrong sign. So, we see a number of significant coefficients for liquidity risk, but we also see that models of the required return are difficult to estimate, including the standard model of market risk (CAPM) and our model of liquidity risk (LCAPM).

While the standard CAPM is difficult to estimate precisely and often rejected empirically, it remains a cornerstone of finance due to its inescapable logic: Investors really should require a higher expected return for securities that add more risk to their portfolio. There is also a strong logic behind the pricing of liquidity and liquidity risk. Liquidity costs are not a phantom menace - investors experience trading costs (commissions, bid-ask spreads, market impact) every day, and, clearly, these trading costs vary across securities and over time. The existence of these costs and their variation is a given, the debatable

\footnotetext{
${ }^{3}$ We note that insignificant coefficients are obviously also not evidence against any model. A theory predicts certain relations among economic variables, but not that these relations should be detectable in any dataset. A rejection of a theory has the form of a significant coefficient with the wrong sign, another statistically significant test of a model prediction such as equal risk premiums, or a precisely estimated coefficient of zero.
} 
issue is whether they affect required returns. To see this point via a contradiction, suppose that two securities offer the same gross return, but one is always far more costly to trade; then, wouldn't all investors prefer the security that can be traded cheaply and easily? If so, the illiquid security must offer a higher gross return to encourage some investors to hold it. That is, liquidity should affect required returns. Further, if liquidity matters and liquidity varies, then must not liquidity risk matter? In other words, if the level of liquidity affects the price, then liquidity shocks lead to price shocks, so shouldn't investors care about this risk? For example, if one security is always easy to trade while another becomes very costly to trade during crisis periods, then wouldn't all investors buy the former unless the security with the higher liquidity risk offers a higher expected gross return?

If liquidity risk matters, why would it matter in a way that nevertheless rejects the specific functional form of our model? There are two types of reasons (i) technical issues with translating the theory issues into empirics, and (ii) the presence of broader types of liquidity risk. Regarding the former, we note the standard concerns that the true market portfolio is not observable, the model is a conditional CAPM with assumptions being made to estimate an unconditional CAPM (assumptions that could be violated in the data), and the overlapping generations model deals with the typical investor's holding period, but it is estimated over a shorter monthly time horizon, again requiring certain assumptions. Another technical issue, also well-known from the standard empirical CAPM literature, is that the liquidity risk parameters are measured with error, which can downward bias their slope coefficients (their estimated premiums) in the cross-sectional analysis. Beyond these technical issues, the model is clearly a simplification of the real world. Indeed, the real world is far more complex and, as a result, so is the pricing of liquidity risk. We believe that it is an important area for future research to enhance the model and empirical evidence of the pricing of liquidity risk.

Other studies also find that market liquidity risk affects the required returns of stocks. For example, since small stocks tend to be illiquid, especially during crises, the size effect (Banz 1981) can be seen as evidence of a liquidity (risk) premium and, while the size premium has varied over time, the size premium appears robust and significant when controlling for stocks' quality characteristics (Asness et al. (2018)); Pástor and Stambaugh (2003) provide an influential study of liquidity risk using a liquidity measure that they develop; Korajczyk and Sadka (2008) and Kim and Lee (2014) find that combining multiple liquidity measures strengthen their results; Bekaert, Harvey, and Lundblad (2007) find evidence of the pricing of liquidity risk in emerging markets; Lee (2011) provides global evidence; Butt and Virk (2015) provide evidence from Nordic markets; Amihud (2014) considers an illiquid-minus-liquid factor and loadings on this factor; Albuquerque, Yao, and Song (2017) consider an exogenous shock to liquidity based on Security Exchange Commission (SEC)'s tick-size experiment; Watanabe and Watanabe (2007) find evidence of time-varying liquidity risk, where liquidity risk is mostly priced during "bad times"; and, Anthonisz and Putninšs (2017) find a strong effect of "downside liquidity risk," that is, an asymmetric version of $\beta_{t}^{4}$ where stock liquidity is especially sensitive to negative market returns. On the other hand, some studies find only weak results, e.g., Hasbrouck (2009) using his measure of liquidity, and the magnitude of the liquidity risk premium is certainly difficult to estimate accurately.

Further, market liquidity effects have been found in other markets such as corporate bond markets (Bao, Pan, and Wang (2011), Lin, Wang, and Wu (2011), Acharya, Amihud and Bharath (2013)), 
government bond markets (Beber, Brandt, and Kavajecz (2008)), private equity (Franzoni, Nowak, and Phalippou (2012)), foreign exchange markets (Mancini, Ranaldo, and Wrampelmeyer (2013)), and derivatives markets (Bongaerts, de Jong, and Driessen (2011)). Interestingly, market liquidity risk can also cause spillovers across securities and markets, and induce correlation risk (Acharya, Schaefer and Zhang (2015)).

\section{Investment management with market liquidity risk}

Investors must take liquidity considerations into account when constructing their optimal portfolio. Professional investors estimate the risk and expected return of each asset in their investment universe, and the costs of trading these assets now and in the future. Each investor must decide how to adjust her portfolio today, taking into account that she will solve a similar problem in each trading period in the future.

Solving the optimal portfolio problem with liquidity risk or even fixed transaction costs can be challenging. For example, in models with fixed transaction costs modelled as proportional bid-ask spreads, Constantinides (1986) relies on numerical solutions even with a single asset with independent and identically distributed (i.i.d.) returns, while Amihud and Mendelson (1986) provide an explicit solution relying on risk neutrality. Our model, Acharya and Pedersen (2005), delivers an explicit equilibrium with risk-averse agents facing transaction costs that vary over time and across many assets. To achieve this tractability, we rely on an overlapping generations model where agents are forced to liquidate their portfolio in each time period.

When transaction costs are quadratic (capturing the idea of market impact), the portfolio problem becomes tractable even when expected returns vary over time and across assets, as shown by Garleanu and Pedersen (2013) who use quadratic programming techniques that are also used in macroeconomics and other fields (see, e.g., Ljungqvist and Sargent (2004)). In this case, the investor optimally trades gradually toward the time-varying Markowitz portfolio, that is, toward the optimal solution in the absence of trading costs. Collin-Dufresne, Daniel, and Saglam (2018) show how to extend this framework to solve the optimal dynamic portfolio problem with liquidity risk.

Empirically, liquidity risk has been found to influence the cross-section of hedge-fund returns (Sadka (2010) and Teo (2011)) and mutual fund returns (Dong, Feng, and Sadka (2019)). Liquidity effects can also help explain the existence and pricing of closed-end funds (Cherkes, Sagi, and Stanton (2008)).

Finally, a recent literature models explicitly that investment often involves a two-tiered process where investors look for good asset managers and asset managers look for good securities. For example, Stambaugh (2014) studies how liquidity and asset management can help explain recent trends in financial markets. Vayanos and Woolley (2013) model asset managers and illiquidity due to time-varying proportional costs to explain momentum and reversals in asset prices. Garleanu and Pedersen (2018) introduce asset managers into a Grossman and Stiglitz (1980) economy, showing how search and information frictions help explain the returns of investors, investment managers, and securities, and how market efficiency is determined. 


\section{Corporate finance with market liquidity risk}

Market liquidity risk affects firms in various ways. For example, the market liquidity of a firm's stock affects the cost of issuing new equity. Indeed, a more liquid stock market is associated with a lower underwriting fee (Butler, Grullon, and Weston (2005)) and lower average underpricing (Corwin (2003)). Similarly, Ellul and Pagano (2006) find that the "expected after-market liquidity and liquidity risk are important determinants of IPO underpricing". Further, the market liquidity influences how many shares firms issue (Stulz, Vagias, and Dijk (2012)) and the method of raising capital (Gao and Ritter (2010)). Similarly, when firms issue corporate bonds, they can issue these bonds at lower yields if the secondary market for the corporate bond is expected to be more liquid (Goldstein, Hotchkiss, and Pedersen (2019)). Goldstein, Hotchkiss, and Pedersen (2019) conclude that "liquidity has an important effect on firms' cost of capital."

Further, there is some evidence that market liquidity affects firms' capital structure decisions. For instance, Lipson and Mortal (2009) find that "firms with more liquid equity have lower leverage and prefer equity financing when raising capital". In a corporate debt context, He and Xiong (2012) and Morris and Shin (2015) show how the inability to roll over debt, a form of market liquidity risk, can affect a firm's solvency risk, and in turn, its probability of default and the ex-ante cost of issuing debt. One would also expect that differences in the cost of capital affect real investments. Ağca and Mozumdar (2008) provide some evidence on this effect. Edmans, Fang, and Zur (2013) find a "positive effect of stock liquidity on blockholder governance."

\section{Banking with market liquidity risk}

In the banking context, the idea of market liquidity risk takes center stage when banks need to sell financial assets (such as loans, asset-backed securities, marketable securities, etc.) to other financial intermediaries in order to raise economic or regulatory capital. How such illiquidity in asset sale markets can affect bank behavior and lead to aggregate banking crises has been the focus of an important body of banking and banking crises models developed notably by Diamond and Rajan $(2002,2005,2011)$.

Effects of market liquidity risk on banking outcomes can be multi-dimensional, leading to a rise in economy-wide discount rates due to market-clearing constraints (Diamond and Rajan (2005)), inducing strategic behavior in inter-bank lending markets by healthy banks as they seek even steeper fire-sale discounts (Acharya, Gromb and Yorulmazer (2012)), generating a "seller's strike" by weak banks as they bet on government or regulatory bailouts (Diamond and Rajan (2011)), and incentivizing precautionary hoarding by banks in order to benefit from full-blown crises (Acharya, Shin and Yorulmazer (2011) and Diamond and Rajan (2011)). Such outcomes that are rooted in market liquidity risk have deleterious effects on the real economy and are being increasingly modeled in new generation banking models (Cornett, McNutt, Strahan, and Tehranian (2011)). 


\section{Financial crises and market liquidity risk}

Clearly financial crises have severe consequences for the real economy (Reinhart and Rogoff (2014)). Financial crises often happen when market liquidity and funding liquidity deteriorate in a mutually reinforcing spiral (Brunnermeier and Pedersen (2009), Geanakoplos (2009)) as everyone runs for the exit (Pedersen (2009)) and anticipation of future liquidity risk, even relatively small, can cause markets for short-term debt - which may have to be rolled over several times before the underlying asset matures to entirely freeze (Acharya, Gale, and Yorulmazer (2011)). The global financial crisis 2007-2009 provided a recent example of these dynamics (Brunnermeier (2009)).

\section{Macroeconomics, monetary, and fiscal policy with market liquidity risk}

Market liquidity varies systematically over the business cycle (Næs, Skjeltorp, and $\varnothing$ degaard (2011)) and several theories seek to incorporate financial frictions into models of the macroeconomy (see Brunnermeier, Eisenbach, and Sannikov (2013) for a survey, or Cui and Radde (2016) for a recent searchbased model). Liquidity can affect the transmission of monetary policy (Lagos and Zhang (2018)).

Central banks try to manage the liquidity of markets through their quantitative easing, credit easing, and other forms of unconventional monetary policy. This liquidity management can serve as a second monetary tool, in addition to the traditional tool of controlling the short-term interest rate (Ashcraft, Garleanu, and Pedersen (2010), and Kiyotaki and Moore (2012)).

\section{Other areas of economics: labor and beyond}

Many other areas of economics are also affected by imperfect markets. A good example is the labor market, which has long been recognized to be full of frictions, often modeled using search models. Further, liquidity disruptions in the security markets can spill over into the labor markets (see, Chodorow-Reich (2014) and Berton, Mocetti, Presbitero, and Richiardi (2018)) and lead to contagion across markets and countries (e.g., Jotikasthira, Lundblad, and Ramadorai (2012)).

\section{Conclusion: liquidity risk handcuffs the invisible hand}

Traditionally, economic analysis assumes that markets are flawless, that is, frictionless with perfect liquidity. In such "invisible-hand" models, asset prices and required returns only depend on cash flow fundamentals, the law of one price determines all derivative prices, all investors buy the market portfolio and risk-free bills (two-fund separation) and never convert a convertible bond or exercise a call option before maturity (Merton's rule), firms invest in all positive net-present value projects based on an irrelevant capital structure (Modigliani-Miller), all business cycles are driven by real effects such as technological progress, Ricardian equivalence limits fiscal policy, and monetary policy is only focused on the interest rate (Taylor rule). 
We argue that liquidity risk fundamentally changes these pillars of economic theory. The risk of a "handcuffed invisible hand" affects investors' portfolio decisions, influences asset prices and required returns, makes the law of one price break down, and implies that corporations face liquidity constraints that depend on their capital structure and affect their real investments. Moreover, liquidity crises can drive business cycles, unconventional monetary policy seeks to improve market liquidity and limit liquidity risk, and fiscal policy depends on the liquidity of the market. Further exploring how liquidity risk affects economic dynamics - and what to do about it-is a fruitful avenue for future research. 


\section{References}

Acharya, Viral V., Yakov Amihud, and Sreedhar T. Bharath. 2013. "Liquidity Risk of Corporate Bond Returns: A Conditional Approach". Journal of Financial Economics, 110 (2), 358-386.

Acharya, Viral V., Douglas Gale and Tanju Yorulmazer. 2011. "Rollover risk and market freezes." Journal of Finance, 66, 1175-1207.

Acharya, Viral V., Denis Gromb and Tanju Yorulmazer. 2012. "Imperfect Competition in the Inter-Bank Market for Liquidity as a Rationale for Central Banking." American Economic Journal Macroeconomics, 4(2), 184-2017.

Acharya, Viral V. and Lasse Heje Pedersen. 2005. "Asset Pricing with Liquidity Risk". Journal of Financial Economics, 77(2), 375-410.

Acharya, Viral V., Stephen Schaefer and Yili Zhang. 2015. "Liquidity Risk and Correlation Risk: A Clinical Study of the General Motors and Ford Downgrade of 2005." Quarterly Journal of Finance, 5(2), 1-51.

Acharya, Viral V., Hyun-Song Shin and Tanju Yorulmazer. 2011. "Crisis Resolution and Bank Liquidity". Review of Financial Studies, 24(6), 2166-2205.

Ağca, Şenay, and Abon Mozumdar. 2008. "The Impact of Capital Market Imperfections on InvestmentCash Flow Sensitivity". Journal of Banking \& Finance, 32 (2), 207-216.

Albuquerque, Rui A., Shiyun Song, and Chen Yao. 2017. "The Price Effects of Liquidity Shocks: A Study of SEC's Tick-Size Experiment". Discussion Paper No. 12486. Centre for Economic Policy Research.

Amihud, Yakov. 2002. "Illiquidity and stock returns: cross-section and time-series effects." Journal of Financial Markets, 5 (1), 31-56.

Amihud, Yakov. 2014. "The Pricing of the Illiquidity Factor's Systematic Risk". Working Paper. SSRN Electronic Journal.

Anthonisz, S., and T. Putniňš. 2017. "Asset Pricing with Downside Liquidity Risks". Management Science, 63(8), 2549-2572.

Ashcraft, Adam, Nicolae Gârleanu, and Lasse H. Pedersen. 2010. "Two Monetary Tools: Interest Rates and Haircuts". NBER Macroeconomics Annual, 25 (1), 143-180.

Asness, Clifford, Andrea Frazzini, Ronen Israel, Tobias J. Moskowitz, and Lasse H. Pedersen. 2018. "Size matters, if you control your junk". Journal of Financial Economics, 129 (3), 479-509.

Banz, R. 1981. "The relationship between return and market value of common stocks." Journal of Financial Economics, 9, 3-18.

Bao, Jack, Jun Pan, and Jiang Wang. 2011. "The Illiquidity of Corporate Bonds". Journal of Finance, 66 (3), 911-946. 
Beber, Alessandro, Michael W. Brandt, and Kenneth A. Kavajecz. 2008. "Flight-to-Quality or Flight-toLiquidity? Evidence from the Euro-Area Bond Market". Review of Financial Studies, 22 (3), 925-957.

Bekaert, G., C. R. Harvey, and C. Lundblad. 2007. "Liquidity and expected returns: Lessons from emerging markets." The Review of Financial Studies, 20 (6), 1783-1831.

Berton, Fabio, Sauro Mocetti, Andrea F. Presbitero, and Matteo Richiardi. 2018. "Banks, Firms, and Jobs". Review of Financial Studies, 31 (6), 2113-2156.

Bongaerts, D., F. de Jong, and J. Driessen. 2011. "Derivative Pricing with Liquidity Risk: Theory and Evidence from the Credit Default Swap Market." The Journal of Finance, 66(1), 203-240.

Brunnermeier, Markus K. 2009. "Deciphering the Liquidity and Credit Crunch 2007-2008". Journal of Economic Perspectives, 23 (1), 77-100.

Brunnermeier, Markus K., and Lasse H. Pedersen. 2009. "Market Liquidity and Funding Liquidity". Review of Financial Studies, 22 (6), 2201- 2238.

Brunnermeier, Markus K., Thomas M. Eisenbach, and Yuliy Sannikov. 2013. "Macroeconomics with Financial Frictions: A Survey". Chapter in Advances in Economics and Econometrics: Tenth World Congress, edited by Daron Acemoglu, Manuel Arellano, and Eddie Dekel, 2:3-94. Econometric Society Monographs. Cambridge: Cambridge University Press.

Butler, Alexander W., Gustavo Grullon, and James P. Weston. 2005. "Stock Market Liquidity and the Cost of Issuing Equity". Journal of Financial and Quantitative Analysis, 40 (2), 331-348.

Butt, Hilal Anwar, and Nader Shahzad Virk. 2015. "Liquidity and asset prices: an empirical investigation of the Nordic stock markets." European Financial Management, 21 (4), 672-705.

Cherkes, Martin, Jacob Sagi, and Richard Stanton. 2008. "A Liquidity-Based Theory of Closed-End Funds". Review of Financial Studies, 22 (1), 257-297.

Chodorow-Reich, Gabriel. 2014. "The Employment Effects of Credit Market Disruptions: Firm-Level Evidence from the 2008-9 Financial Crisis". Quarterly Journal of Economics, 129 (1), 1-59.

Chordia, T., R. Roll, and A. Subrahmanyam. 2000. "Commonality in liquidity." Journal of Financial Economics, 56, 3-28.

Collin-Dufresne, Pierre, Kent Daniel, and Mehmet Sağlam. 2018. "Liquidity Regimes and Optimal Dynamic Asset Allocation". Working Paper No. 24222. National Bureau of Economic Research.

Constantinides, George M. 1986. "Capital Market Equilibrium with Transaction Costs". Journal of Political Economy, 94 (4), 842-862.

Cornett, Marcia M., Jamie J. McNutt, Philip E. Strahan, and Hassan Tehranian. 2011. "Liquidity Risk Management and Credit Supply in the Financial Crisis". Journal of Financial Economics, 101 (2), 297312. 
Corwin, Shane A. 2003. "The Determinants of Underpricing For Seasoned Equity Offers". Journal of Finance, 58 (5), 2249-2279.

Cui, Wei, and Sören Radde. 2016. "Search-Based Endogenous Asset Liquidity and the Macroeconomy". Working Paper No. 1917. European Central Bank.

Diamond, Douglas and Raghuram G. Rajan. 2002. "Bank Bailouts and Aggregate Liquidity Shortages", American Economic Review (Papers and Proceedings), 92 (2), 38-41.

Diamond, Douglas and Raghuram G. Rajan. 2005. "Liquidity Shortages and Banking Crises", Journal of Finance, 60(2), 615-647.

Diamond, Douglas and Raghuram G. Rajan. 2011. "Fear of Fire Sales, Illiquidity Seeking, and Credit Freezes", Quarterly Journal of Economics, 126(2), 557-591.

Dong, Xi, Shu Feng, and Ronnie Sadka. 2019. "Liquidity Risk and Mutual Fund Performance". Management Science, 65(3), 1020-1041.

Alex Edmans, Vivian W. Fang, and Emanuel Zur. 2013. "The Effect of Liquidity on Governance". The Review of Financial Studies, 26 (6), 1443-1482.

Ellul, Andrew, and Marco Pagano. 2006. "IPO Underpricing and After-Market Liquidity". Review of Financial Studies, 19 (2), 381-421.

Fama, Eugene F., and Kenneth R. French. 2004. "The capital asset pricing model: Theory and evidence". Journal of economic perspectives, 18(3) , 25-46.

Franzoni, F., E. Nowak, and L. Phalippou. 2012. "Private Equity Performance and Liquidity Risk". The Journal of Finance, 67(6), 2341-2373.

Friewald, Nils, Rainer Jankowitsch, and Marti G. Subrahmanyam. 2012. "Illiquidity or Credit Deterioration: A Study of Liquidity in the US Corporate Bond Market during Financial Crises". Journal of Financial Economics, 105 (1), 18-36.

Gao, Xiaohui, and Jay R. Ritter. 2010. "The Marketing of Seasoned Equity Offerings". Journal of Financial Economics, 97 (1), 33-52.

Gârleanu, Nicolae, and Lasse H. Pedersen. 2013. "Dynamic Trading with Predictable Returns and Transaction Costs". Journal of Finance, 68 (6), 2309-2340.

Gârleanu, Nicolae, and Lasse H. Pedersen. 2018. "Efficiently Inefficient Markets for Assets and Asset Management". Journal of Finance, 73 (4), 1663-1712.

Geanakoplos, John. 2009. "The Leverage Cycle". NBER Macroeconomics Annual 24: 1-66.

Goldstein, Michael A., Edith S. Hotchkiss, and David J. Pedersen. 2019. "Secondary Market Liquidity and Primary Market Pricing of Corporate Bonds." Journal of Risk and Financial Management, 12 (2), 86. 
Grossman, Sanford J., and Joseph E. Stiglitz. 1980. "On the Impossibility of Informationally Efficient Markets". American Economic Review, 70 (3), 393-408.

Hasbrouk, J. 2009. "Trading Costs and Returns for U.S. Equities: Estimating Effective Costs from Daily Data." The Journal of Finance, 64(3), 1445-1477.

Hasbrouck, J., Seppi, D.J., 2001. "Common factors in prices, order flows and liquidity." Journal of Financial Economics, 59, 383-411.

He, Zhiguo and Wei Xiong, 2012. "Rollover risk and credit risk." Journal of Finance, 67(2), 391-429.

Holden, Craig W. and Jayoung Nam. 2019. "Testing the LCAPM vs. Generalized Liquidity-Adjusted Asset Pricing: New Evidence and New Perspectives". Critical Finance Review, this issue.

Jotikasthira, Chotibhak, Christian Lundblad, and Tarun Ramadorai. 2012. "Asset Fire Sales and Purchases and the International Transmission of Funding Shocks". Journal of Finance, 67 (6), 2015-2050.

Kazumori, Eiichiro, Fei Fang, Raj Sharman, Fumiko Takeda, and Hong Yu. 2019. "Asset Pricing with Liquidity Risk: A Replication and Out-of-Sample Tests with the Recent US and the Japanese Market Data". Critical Finance Review, this issue.

Kim, Soon-Ho, and Kuan-Hui Lee. 2014. "Pricing of Liquidity Risks: Evidence from Multiple Liquidity Measures". Journal of Empirical Finance, 25, 112-133.

Kiyotaki, Nobuhiro, and John Moore. 2012. "Liquidity, Business Cycles and Monetary Policy". Working Paper No. 17934. National Bureau of Economic Research.

Korajczyk, R. and R. Sadka. 2008. "Pricing the commonality across alternative measures of liquidity". Journal of Financial Economics, 87(1), 45-72.

Lagos, Ricardo, and Shengxing Zhang. 2018. "Turnover Liquidity and the Transmission of Monetary Policy". Working Paper No. 25106. National Bureau of Economic Research.

Lee, K. 2011. "The world price of liquidity risk." Journal of Financial Economics, 99(1), 136-161.

Lin, Hai, Junbo Wang, and Chunchi Wu. 2011. "Liquidity Risk and Expected Corporate Bond Returns". Journal of Financial Economics, 99 (3), 628-650.

Lipson, Marc L., and Sandra Mortal. 2009. "Liquidity and Capital Structure". Journal of Financial Markets, $12(4), 611-644$.

Ljungqvist, Lars, and Thomas Sargent. 2004. Recursive Macroeconomic Theory. 2nd ed. Cambridge, MA: The MIT Press.

Mancini, L., A. Ranaldo, and J. Wrampelmeyer. 2013. "Liquidity in the Foreign Exchange Market: Measurement, Commonality, and Risk Premiums". The Journal of Finance, 68(5), 1805-1841. 
Morris, Stephen and Hyun Song Shin. 2015. "Illiquidity component of credit risk." International Economic Review, 57(4), 1135-1148.

Pástor, L'uboš, and Robert F. Stambaugh. 2003. "Liquidity risk and expected stock returns." Journal of Political Economy, 111(3), 642-685.

Pedersen, Lasse H. 2009. "When Everyone Runs for the Exit". The International Journal of Central Banking, 5 (4), 177-199.

Reinhart, Carmen M., and Kenneth S. Rogoff. 2014. "Recovery from Financial Crises: Evidence from 100 Episodes". American Economic Review, 104 (5), 50-55.

Rogerson, Richard, Robert Shimer, and Randall Wright. 2005. "Search-Theoretic Models of the Labor Market: A Survey". Journal of Economic Literature, 43 (4), 959-988.

Sadka, Ronnie. 2010. "Liquidity Risk and the Cross-Section of Hedge-Fund Returns". Journal of Financial Economics, 98 (1), 54-71.

Stambaugh, Robert F. 2014. "Investment Noise and Trends". Journal of Finance, 69 (4), 1415-1453.

Stulz, René M., Dimitrios Vagias, and Mathijs A. Van Dijk. 2012. "Do Firms Issue More Equity When Markets are More Liquid?". Working Paper No. 19229. National Bureau of Economic Research.

Teo, Melvyn. 2011. "The Liquidity Risk of Liquid Hedge Funds". Journal of Financial Economics, 100 (1), $24-44$

Vayanos, Dimitri, and Paul Woolley. 2013. "An Institutional Theory of Momentum and Reversal”. Review of Financial Studies, 26 (5), 1087-1145.

Watanabe, Akiko, and Masahiro Watanabe. 2007. "Time-varying liquidity risk and the cross section of stock returns." The Review of Financial Studies, 21 (6), 2449-2486. 